\title{
Application of Traditional Ecological Knowledge in Food and Water Security in the Semi-Arid Turkana County, Kenya
}

\author{
Cecilia Mwango Ratemo', George Morara Ogendi'2,3 (), Guangwei Huang1, Rhoda N. Ondieki ${ }^{3}$ \\ ${ }^{1}$ Graduate School of Global Environmental Studies, Sophia University, Tokyo, Japan \\ ${ }^{2}$ Department of Environmental Science, Egerton University, Njoro, Kenya \\ ${ }^{3}$ Dryland Research Training and Ecotourism Centre, Chemeron, Kenya \\ Email: ceciliaratemo@gmail.com, gmorara2009@gmail.com
}

How to cite this paper: Ratemo, C.M., Ogendi, G.M., Huang, G. and Ondieki, R.N. (2020) Application of Traditional Ecological Knowledge in Food and Water Security in the Semi-Arid Turkana County, Kenya. Open Journal of Ecology, 10, 321-340. https://doi.org/10.4236/oje.2020.106020

Received: April 27, 2020

Accepted: May 28, 2020

Published: June 1, 2020

Copyright $\odot 2020$ by author(s) and Scientific Research Publishing Inc. This work is licensed under the Creative Commons Attribution International License (CC BY 4.0).

http://creativecommons.org/licenses/by/4.0/

\begin{abstract}
Weather extremes negatively affect socioeconomic developments in arid and semi-arid areas (ASALs) and increase vulnerability of residents to food and water insecurity. Thus, communities adapt to such extremes of weather using Traditional Ecological Knowledge (TEK) and/or Modern Technologies. Modern farming technologies and land resource developments in ASALs have in past ignored TEK, and in most cases led to undesired outcomes. It's against this backdrop that this study was conceived to assess TEK among the Turkana people, its application and contribution to food and water security. The research adopted a cross-sectional social survey in collecting data from Central Turkana Sub-County residents. The study revealed that the Turkana people possess vast knowledge related to their environment; that this TEK plays a significant role in food production, preservation and in natural resource management. For instance, in $82 \%$ of the respondents use TEK in enhancing livestock production through the selection of livestock species that are suitable and drought tolerant; over $70 \%$ of them use TEK in reducing risk associated with livestock losses due to prolonged droughts. Further, TEK influenced the development and conservation of the water resources $(r=0.631 ; p$ $<0.01)$ including siting boreholes and wells. There was a strong correlation ( $\mathrm{r}$ $=0.755 ; \mathrm{p}<0.01$ ) between TEK and food security. TEK should be incorporated into the decision-making processes involving development projects within the ASALs.
\end{abstract}

\section{Keywords}

Arid and Semi-Arid Lands, Climate Variability, Droughts, Food Security, Traditional Ecological Knowledge, Water Security 


\section{Introduction}

Land degradation in drylands is an issue of global concern due to the unsustainable resource use and increasing impacts to local communities [1] [2]. UNCCD defines land degradation as the reduction of biological or economic productivity of land as a result of unwise use from human activities or from natural induced factors. Dryland degradation is exacerbated by either or both natural and anthropogenic factors all which may lead to desertification [3] [4]. Natural factors which include climatic variations could manifest in droughts interfering with hydrological systems and agricultural output. Having persistent droughts, the dryland ecosystems are expected to become drier hence food production and water sources could be adversely affected heightening the risks and vulnerability of the local populations [5] [6]. Globally the frequencies and intensities of droughts have increased, with countries like Australia, Russia, Southwestern China being affected by prolonged events in the years 2002 to 2012. Africa is also prone to droughts being evident in the Sahel region and the Horn of Africa with countries such as Kenya, Somalia and Ethiopia experiencing extreme events [7] [8] [9] [10].

Dryland developments, which may come in the form of introduced modern agricultural technologies, seem to threaten these ecosystems. High water utilization and soil degradation are some of the effects of the introduced technologies [1]. Irrigation is an example of technological advancement initiated in ASAL regions to supplement dryland farming. Boosting food production has always been the goal of farming and irrigation in these regions. However, as much as food security is the output, the challenge comes in the utilization and competition of the scarce water sources [11]. Globally fresh water sources are limited and the two main sectors involved in major withdrawals are agriculture and industries [12]. In the agriculture sector, irrigation contributes to approximately $70 \%$ of water withdrawals which is estimated to peak to $90 \%$ and above in developing countries [13]. Aside from the water scarcity issue in drylands, a second notable effect is soil degradation. Some studies have observed that close to 40 million hectares of irrigated land in global drylands are affected by water logging, soil salinization and sodication [14]. Soil salinity is more peculiar as it not only affects the irrigated lands but also non-irrigated areas. The accumulation of salts can occur naturally due to high evaporation rates but may also be worsened with use of saline ground water sources, inadequate water management and poor drainage systems [15] [16].

ASAL communities are alarmingly endangered by land degradation and desertification [14]. Nevertheless, excluding the external development effects, indigenous communities in these ecosystems have consistently survived the unstable and resource scarce environments for decades. They are believed to be resilient and adapted some coping mechanisms that have enabled them to live with the fluctuating conditions. Being excellent examiners of the environment, indigenous people have developed rich sets of explanations and various systems of 
dealing with natural hazards. Owing to their good interactions with nature, the communities have utilized their experiences in solving complex issues and ultimately in safeguarding their natural resources. This wisdom has been passed down from generation to generation giving them additional skills in disaster prevention, mitigation and in early warning systems [17]. Indigenous peoples' cumulative knowledge, practices and beliefs that are distinct to a local culture which includes their relationship with one another and the environment is referred to as Traditional Ecological Knowledge (TEK) [18].

Turkana County in Kenya is one of the Arid and Semi-arid counties that is prone to environmental degradation. The County has been facing climatic shocks with droughts being a common phenomenon and unsustainable use of land and water resources, hastened by the increasing development activities [19] [20]. Irrigation projects in Turkana were mainly initiated by external investors and the Kenyan government with the purpose of alleviating poverty and boosting food security in this ASAL. In line with its National Policy for Sustainable Development of Northern Kenya and Other Arid lands, the Kenyan government sought to diversify the livelihoods of the Turkana people as a way of addressing the challenges the communities were facing [21]. However, the Turkana people since colonial times have been dependent on pastoralism as their main source of livelihood, which based on their experiences, has been a viable option considering their unstable environment.

The lives of Turkana residents are at risk because not only are they affected by the unsustainable modern agricultural technologies, that have proven to be inconsistent and unreliable, but also is climate variability and change issues ultimately affecting their food production and water systems. Besides being an ASAL region, Turkana still experiences harsh weather conditions with frequent droughts in the area interfering with the regions agricultural systems [22]. Thus, in spite of the major governmental and non-governmental agencies' drought mitigations measures including donors' technological support and modern climate-smart interventions, there are still widespread cases of food and water insecurity. The modern agricultural technologies have not alleviated the hunger and starvation that epitomizes the ASAL communities in Kenya. The irrigation projects have not been as successful and have often recorded low productivity in the existing schemes [19].

Central Turkana community like many other ASAL communities is believed to possess substantial knowledge relating to agricultural production as well as water conservation. These skills and knowledge are prescientific and used by different generations to promote wise resource use through designing of sustainable and resilient systems of production. The traditional ecological systems seem to be eroding as many indigenous groups are losing their values due to modernization [23]. In addition to erosion of TEK systems, its documentation is limited. This study therefore focused on assessing Traditional Ecological knowledge of the Turkana Community and evaluating its contribution to food and water security. Specifically, the study aimed at: 1) describing the utilization of 
TEK in food production, preservation and in water resource management, and 2) identifying and documenting various forms of TEK used in Natural Resource Management.

\section{Methodology}

\subsection{Description of Study Area}

Turkana County is located in Northwest region, Kenya and is bordered by Uganda, Sudan and Ethiopia to the West, North and North east respectively. The County occupies an area of $68,860 \mathrm{~km}^{2}$ [24] and is further divided into 6 constituencies which include; Turkana Central, Turkana North, Turkana West, Loima, Turkana East and Turkana South. The County headquarters is in Lodwar, Turkana Central, which is considered to have the highest density of people owing to the availability of social amenities and economic opportunities. Turkana's has received world-wide fame as the purported "Cradle of Mankind", for the early hominids, including remains of various Australopithecus species, Homo habilis, Homo erectus and Homo sapiens. The research was conducted in different locations of Turkana Central which included Napetet, Kapua, Kawalase and Kalokol trading center (Figure 1). The study was conducted between June and September 2017 . The study area lies within the GPS coordinates $3^{\circ} 07^{\prime} 8.80^{\prime \prime}$

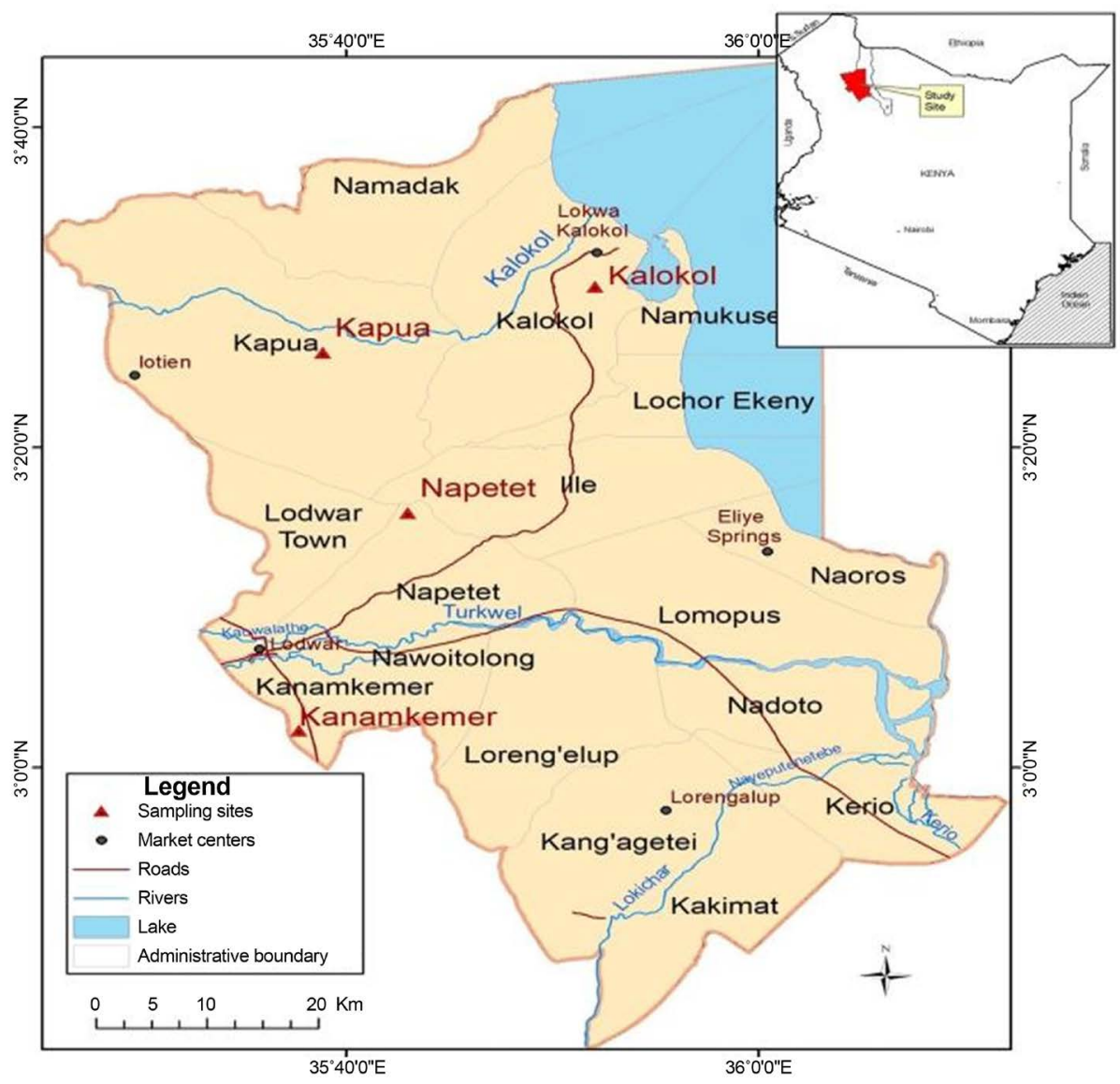

Figure 1. Map of central, Turkana Kenya showing sampling sites. 
North and $35^{\circ} 35^{\prime} 17^{\prime \prime}$ East. Selection of the sampling sites was based on the objectives of this study.

\subsection{Topography, Geology and Hydrology}

Turkana region is characterized by low lying open plains with colluvial, Aeolian and alluvial soils. The soils are not well developed and are prone to water and wind erosion [19]. The high temperatures in the area result in higher evaporation rates with salt deposits being traced in the soils. $30 \%$ of the soils are moderately fit for agriculture and are mostly found in lowlands and river basins [25]. The vegetation is dominated by dwarf shrubs, grasslands and scattered trees of acacia species, Balanites aegyptiaca and Prosopis juliflora which are common sources of fodder for livestock and also provide fuel wood, building material and food for humans [26].

The study area contains both surface and ground water sources. The surface sources include Rivers Kawalase, Turkwel, Kerio, and Lake Turkana. Kawalase is a seasonal River while Kerio and Turkwel are perennial rivers flowing through the Eastern and Northern parts of Central Turkana and draining into Lake Turkana [26]. Lake Turkana, also known as Lake Rudolf, is one of Africa's largest lakes mainly fed by River Omo from Ethiopia which contributes to $95 \%$ of the Lake's water. The lake has no outlet thus with limited inflows and high evaporation rates the waters become saline making it unfit for consumption and agricultural use [27]. Other water sources in the study area include boreholes, wells, springs, dams, pans and rock catchments [28].

\subsection{Climate}

The climate of the study area is characterized as arid and semi-arid with a rating of $42 \%$ (arid), 38\% (very arid) and 19\% (semi-arid) [24]. Central Turkana constituency is located in Agro-ecological zone VI which is one of the driest climatic zones in Kenya [29]. The temperature range for the County varies from $20^{\circ} \mathrm{C}$ to $41^{\circ} \mathrm{C}$ with a general mean of $30.5^{\circ} \mathrm{C}$ [19]. Rainfall patterns in the region are bimodal and erratic with long rains, locally known as Akiporo, occurring between April and July and the short rains occurring between October and November. More rain is experienced in the Western parts of Turkana due to the high elevations. Turkana region collectively records annual rainfall amounts varying from $52 \mathrm{~mm}$ to $480 \mathrm{~mm}$ with an annual mean of $200 \mathrm{~mm}$ [25]. Rain falls in brief violent storms resulting in flush floods which enhance surface runoff.

\subsection{Research and Sampling Design}

The study adopted a cross-sectional survey design. By use of this design, a sample of 100 respondents was selected and structured questionnaires administered to the individuals. This study adopted a sampling frame where a list of households living within the study was generated using the county population statistics. The questionnaire was administered to household respondents that were 
selected using the list with representation across the study area. The respondents were local community members were older than 18 years, and were household heads or represented household heads.

The choice of the design was based on the fact that information about dependent and independent variables gathered should be a representative and not biased [30]. Both qualitative and quantitative data was collected using Focused group discussions (FGD), key informant interviews (KII), personal observations and questionnaires. The data that was collected centered on the study objectives/research questions.

\subsection{Data Analysis}

Data collected using questionnaires and observation checklists were first coded and then entered into an SPSS database. The data was then checked for accuracy and completeness as well as for inconsistencies and missing values. Both descriptive and inferential statistics were employed in analyzing the data. In terms of descriptive statistics, frequencies and valid percentages were used whereas in terms of inferential statistics, Pearson Correlation was employed to analyze the data. The results are presented in the form of tables, pie-charts, figures and photos/plates.

\section{Results and Discussion}

\subsection{Education Level of Respondents}

Among the respondents interviewed, 54\% lacked formal education whereas $23 \%$ had primary level, $14 \%$ had secondary level and only $9 \%$ had received tertiary level education. The low levels of education and enrolment in schools is attributed to the culture and nomadic nature of the community, the long distance to nearby schools and the high incidence of insecurity in the area [25].

\subsection{Sources of Income}

Livestock production was identified as the main source of income (Figure 2) while other activities mainly included businesses, weaving and honey production. Households dependent on livestock rated it as $92.8 \%$ extremely and very important with $4.1 \%$ and $3.1 \%$ giving an impression that it is moderate and slightly important to them, respectively.

Livestock is an important asset and a backbone to the economy of the Turkana community. It contributes to approximately 5.9 billion annually through the sale of animal products and by products [19]. The common species reared in the region are sheep, goats, camels and indigenous cows. Despite its economic contribution, livestock have socio-cultural roles where they are used in rituals and in exchange of gifts and dowry payments [19]. Herding and livestock rearing has been considered Africa's first food production means originating from Eastern Sahara in the Early Holocene period, later spreading West and South into Turkana basin by $4000{ }^{14} \mathrm{C}$ BP [31] [32]. 


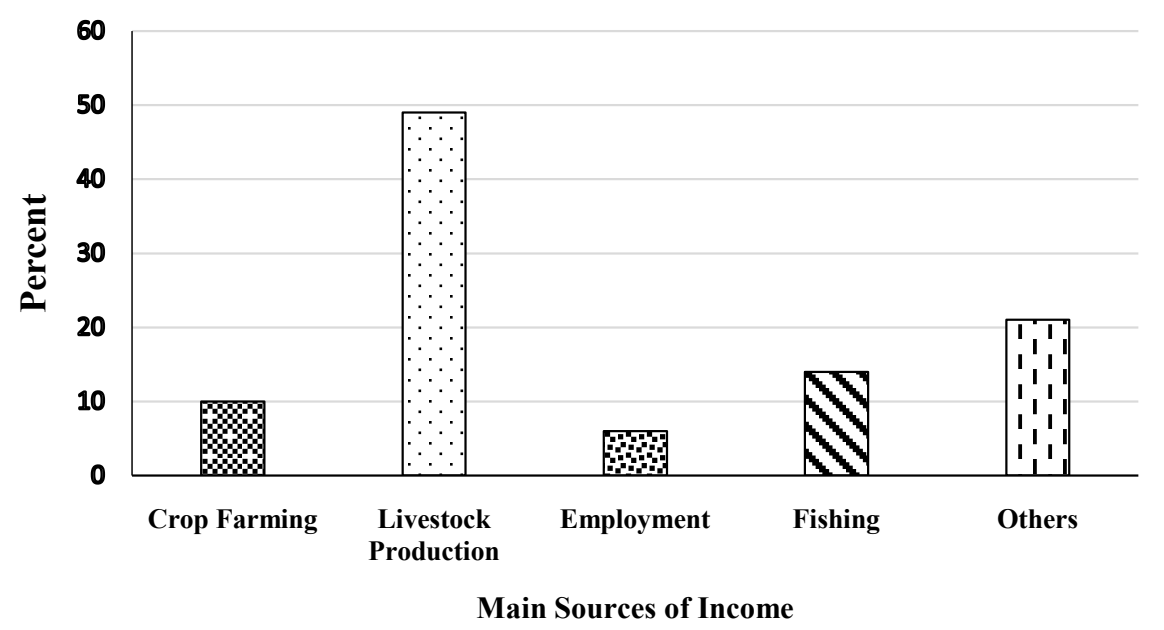

Figure 2. Main source of income in central Turkana, Kenya. Source: Authors' Field Survey (2017).

\subsection{Factors Influencing Food Security}

\subsubsection{Use of TEK}

Seventy-nine percent of the respondents indicated that TEK influences food security, while $21 \%$ gave a negative response. Key areas in which TEK influences, as identified by the locals include; food production and preservation, choice and selection of livestock species, migration patterns, siting and identification of water sources, vegetation conservation and weather prediction. Use of TEK in the above areas is as a result of the communities' constant interaction and observation of the environment. These mechanisms have been used by different generations ultimately enhancing their resilience and survival in this resource scarce environment.

\subsubsection{Diversified Forms of Livelihoods}

In spite of livestock production being the main economic activity of the Turkana community, they as well have adopted other livelihood means to supplement pastoralism. Fishing in Lake Turkana is one of the activities that has boosted food security in the study area specifically during the drought periods. It's a major activity particularly for residents of Kalokol town due to its proximity to the Lake. The fish are distributed and sold to other parts of Turkana County including Lodwar, Napetet, Kanamkemer. In an interview with Kalokol fishermen, 22 out of the 29 interviewed stated that fish was their main source of food and protein; however, in the past couple of years they have experienced decline in fish harvests which they linked to the reduction in water levels and degradation of spawning sites for fish. These observations were in agreement with those of experts from the Ministry of Pastoral Economy and Fisheries (MPEF), and the Kenya Marine and Fisheries Research Institute (KMFRI) who in addition stated that the County battles with climate variability issues which have not only affected food security for residents but also water accessibility.

On the other hand, agro-pastoralism is a livelihood strategy practiced by a 
fraction of the population. Only $10 \%$ of the respondents interviewed practiced crop farming and pastoralism simultaneously. Irrigation is limited to areas that are adjacent to rivers such Turkwelk and Kawalase. River Turkwel is the main source of water supporting most irrigation schemes in Turkana County. Other sources of income that the Turkana community has ventured in include employment, businesses, honey production, mat and basket weaving.

\subsection{Major Droughts and Its Impacts on Food and Water}

The study findings from FGDs and Key Informant Interviews (KIIs) revealed that droughts are a norm to the Turkana residents and as a result they have different coping mechanisms to enhance their survival. Droughts account for huge livelihood losses experienced in the study area. Some of the notable ones that remain vivid to respondents are shown in Table 1.

\subsection{Indigenous Coping Strategies}

\subsubsection{Food Production and Preservation}

The Turkana community has intimate knowledge of their environment and has been able to cope with climate variability. Most of the practices adopted in this arid land emerge out of their observations and experiences over a long period of time. Like any other community, ensuring constant food production and accessibility is central to their survival. Being dependent on livestock and fish as their main sources of food, the residents have well developed strategies for ensuring

Table 1. Droughts and its impacts to food and water in Turkana county.

\begin{tabular}{|c|c|c|}
\hline Year of occurrence & Drought Event and Extent & Impacts on environment and humans \\
\hline 1959-1961 & $\begin{array}{l}\text { Severe drought that affected much of northern } \\
\text { Kenya including Turkana County. } \\
\text { Locally known as Namotor. }\end{array}$ & $\begin{array}{l}\text { Led to loss of human lives, crops, and livestock. Characterized by } \\
\text { shortages in both water and food. }\end{array}$ \\
\hline 1968-1971 & $\begin{array}{l}\text { Very severe drought affecting much of Sub-Saharan } \\
\text { Africa region including Kenya, Ethiopia and Chad. } \\
\text { Locally known as Kimududu/ Kibekbek. }\end{array}$ & Led to famines, reduced water levels and fish harvests in Lake Turkana. \\
\hline $1983-1984$ & $\begin{array}{l}\text { Prolonged drought in Kenya and much of the East } \\
\text { and Central Africa region. Locally known as Kiyoto } \\
\text { atang aal Lopiar. }\end{array}$ & $\begin{array}{l}\text { Drought led to livestock deaths, loss of human lives and crop failure. } \\
\text { Notable and memorable aspects of this drought were the introduction of } \\
\text { food rations and long queues in food distribution centres. }\end{array}$ \\
\hline 1990-1991 & $\begin{array}{l}\text { Severe droughts in the Arid and Semi-Arid Lands of } \\
\text { Kenya } \\
\text { Locally known as Lokwakoyo/ Alkalkal. }\end{array}$ & $\begin{array}{l}\text { Characterized by crop failure, loss of human lives and livestock deaths. } \\
\text { Reduced surface areas of lakes in the region and led to the introduction } \\
\text { of "food for work" programmes. }\end{array}$ \\
\hline $1999-2001$ & $\begin{array}{l}\text { Prolonged drought that affected ASALs as well as } \\
\text { many high potential agricultural areas in Kenya. } \\
\text { Locally known as Logara/ Epompo. }\end{array}$ & $\begin{array}{l}\text { Massive losses in crops and livestock. Government interventions } \\
\text { included construction of water pans, boreholes, and irrigation schemes. }\end{array}$ \\
\hline 2009-2011 & $\begin{array}{l}\text { Extreme drought event in the northern Kenyan } \\
\text { ASALs including Turkana. }\end{array}$ & $\begin{array}{l}\text { Led to loss of human lives, crops and livestock. The extreme event } \\
\text { resulted to a "Kenya for Kenya" relief program coordinated by Kenya } \\
\text { Red Cross that provided food for starving people and initiated irrigation } \\
\text { projects and greenhouses in Turkana County. }\end{array}$ \\
\hline
\end{tabular}

Source: Authors' Field Survey (2017); Ngaira, (2006). 
food production and preservation to enable them deal with climate variability and the attendant challenges caused by prolonged droughts and floods.

\subsubsection{Drought Resistant Animals}

According to the 2005 and 2009 livestock population census data, goats, sheep, cattle, camels are among the common species owned by the Turkana community [33]. The selected animal breeds are adapted to surviving range conditions and this is evident with the Indigenous Turkana cattle breed which is classified as one of the largest East African Zebu species [34]. The Zebu breeds exhibit high drought tolerance qualities portrayed in their capacity to withstand water and pasture scarce environments [35]. Unlike the common grazing animals, goats and camels are good browsers that feed on a wide variety of vegetation from tree parts (leaves, pods, fruits) to bushes and shrubs. However, camel herding has not been a norm for the Turkana community, significant interest arose as a result of desertification [36]. As a food security strategy, camels are a significant livestock species among the Turkana community and as Watson (2016) observes, the one humped camel has been slowly replacing the cattle species in this part of Kenya. This species of camels is hardy and can tolerate the unpredictable climatic conditions being experienced. They are browsers that feed on plants that are not utilized by other conventional animals [37]. Moreover, this camel breed in Turkana is unique in its small body size and feet that makes it swift enough in traversing the steep slope characteristic of the county [38].

\subsubsection{Livestock Risk Reduction Mechanisms}

Turkana pastoralists have adopted a wide range of practices that enable them buffer and mitigate the impacts of droughts and floods. Through reducing the risk of herd loss, they are able to safeguard their livelihoods. $80 \%$ and $73 \%$ of respondents interviewed identified relocation and herd splitting to be the most preferred livestock risk reduction strategies in practice (Figure 3). Relocation allowed pastoralists access feed and water sources in different regions; however,

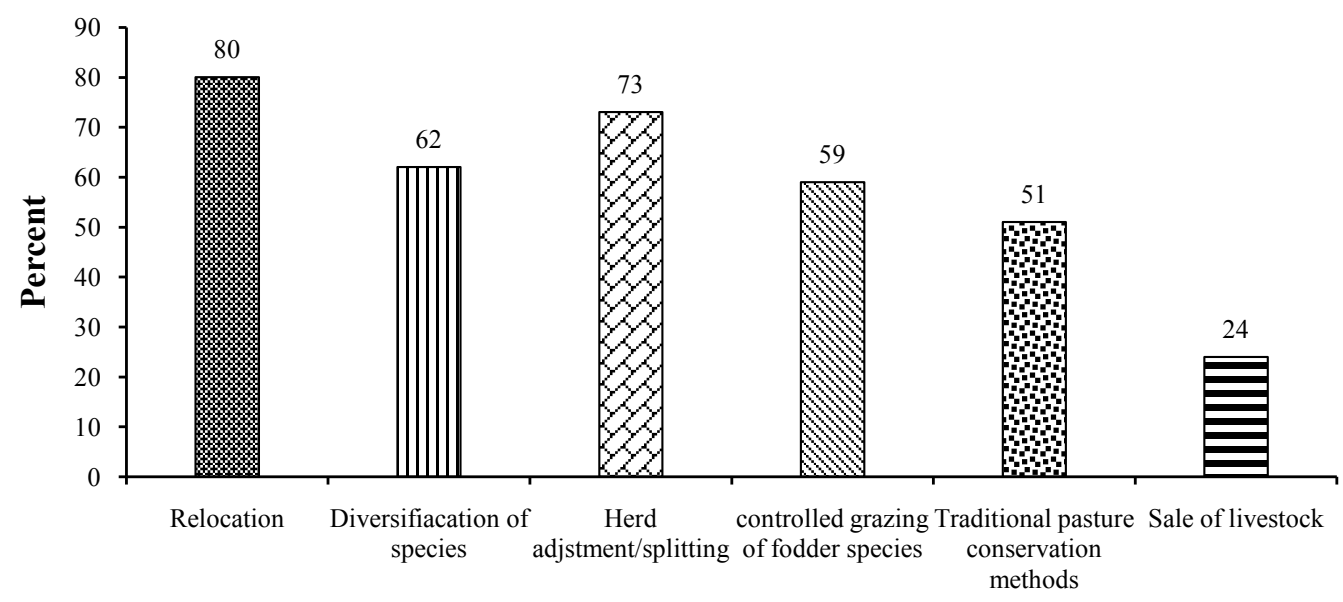

Livestock Risk Reduction Mechanisms

Figure 3. Indigenous livestock risk reduction mechanisms. Source: Authors' Field Survey (2017). 
the herd owner is expected to be in constant movement with the flock. The respondents indicated that the destination and migration routes of pastoralists are determined by their indigenous prediction of the weather and their ability to identify and utilize early warning systems. Herd splitting, and adjustment are also fairly common practices employed by the Turkana community. Other risk reduction mechanisms the community utilize are; diversification of livestock species, controlled grazing of fodder species, traditional pasture conservation methods and sale of livestock.

\subsection{Food Preservation Techniques}

Food preservation is an important step at enhancing food security. It contributes to increased food availability throughout the year. Food insecurity and shortages in Turkana County is mainly triggered by droughts that result in scarcity of water and pastures. Access to food commodities is further compounded by high food prices that interfere with the consumption patterns and the nutrition status of the residents. Some of the respondents indicated that they would skip or reduce the number of meals in a day during harsh drought periods. Other coping mechanisms the community widely practiced include; collection of wild fruits, purchasing of cereals and preservation of perishable foods. 95\% of the respondents used traditional food preservation techniques and very few were familiar with the modern techniques. Four percent of the respondents interviewed used refrigeration as a food preservation technique but its outcome was uncertain as frequent power outages in the area became a limitation to the use of this preservation technique (Table 2). Drying (Figure 4), smoking and salting of perishable food stuff (meat and fish) was a common practice done by the community which resulted in preservation of food for up to 5 years [33]. Use of honey as a preservative to increase the shelf life of items like meat and fish was also practiced by some of the respondents.

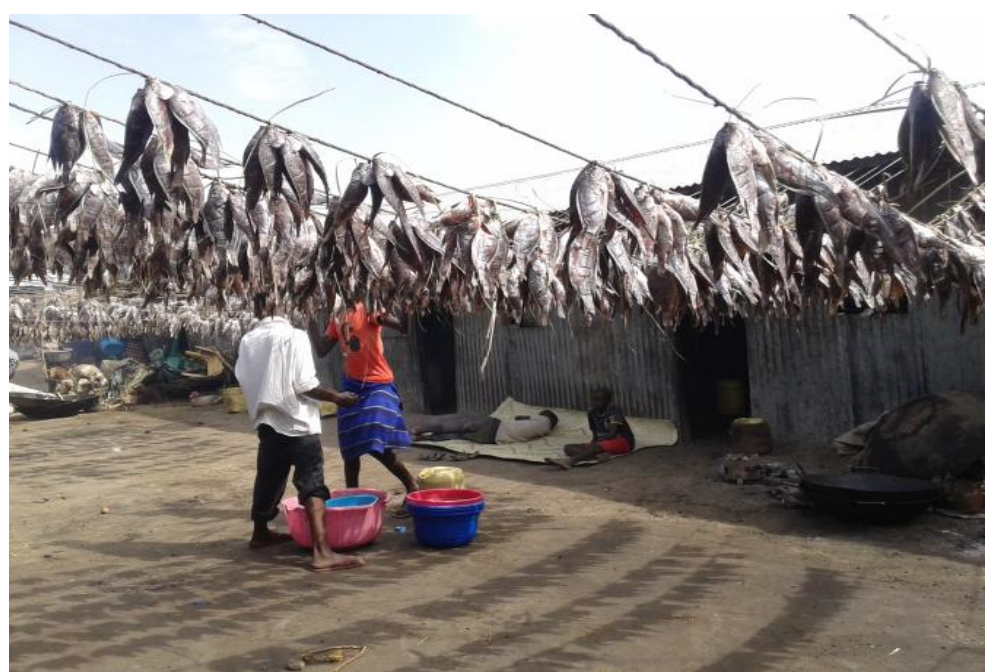

Figure 4. Sun drying of fish at Kalokol, Turkana County, Kenya. Source: Authors' Field Survey (2017). 
Table 2. Traditional and modern techniques used in food preservation.

\begin{tabular}{ccc}
\hline & Valid Percent & Cumulative Percent \\
\hline Drying & 45.5 & 45.5 \\
Smoking & 23.2 & 68.7 \\
Buying cereals in large quantities & 18.2 & 86.9 \\
Salting & 9.1 & 96.0 \\
Refrigeration & 4.0 & 100 \\
Total & 100 & \\
\hline
\end{tabular}

Source: Authors' Field Survey (2017).

\subsection{TEK, Land Use and Natural Resource Management (Vegetation, Water)}

The study revealed that the land tenure system in the area is communal. This means that, no one legally owns land but is rather owned in trust of the community by local authorities. None of the respondents interviewed had title deeds to the lands that they had settled on. Some even indicated that they did not know what a title deed is. From one FGD, it was noted that this kind of land ownership system in Turkana may work in favor of or against the community. In terms of development, it may limit potential investors as transfer of ownership needs to be done through community representatives. As for their nomadic lifestyle one would think that the residents are at liberty to full or unlimited resource access. However, as McCabe [39] illustrates in his paper, "A case against tragedy of the commons," social institutions exist in Turkana that govern utilization of natural resources and most specifically that of pasture and water.

The researcher observed that rights to forage resources are not individually based but are granted on a territorial basis such that every herd owner is limited to graze in particular sections. Certain areas are infrequently utilized and are considered dry season grazing lands. With Ngisonyoka tribe (a local tribe in Turkana), this resource strategy is monitored by the elders of the community and a senior "Emeron" who oversees the whole process.

On the other hand, access to water is limited as it depends on the type of the water source. Flowing waters from rivers, springs have unrestricted access while that of wells is restricted with permission granted to the family of the well digger and close relatives.

\subsubsection{Migration as a Response Strategy}

Pastoralism is an important livelihood activity that enables humans cope with low productive environments and resource-climate uncertainties. The response strategy requires movement of livestock based on seasonal variations. Eighty-two percent of the respondents revealed that their mobility and migration patterns were influenced by their ecological knowledge of weather and vegetation growth patterns. In their views, mobility is a drought adaptation strategy that allows them access to forage and water sources in critical times. Nevertheless, the movement, which is mostly favored by the communal land tenure system, is at risk due to challenges posed by recent and ongoing developments in the area. It 
is anticipated that conflicts may occur if the land is fragmented further or the land use system is changed [40].

\subsubsection{Weather Prediction and Early Warning Systems}

Seventy-six percent of the respondents indicated that they utilized TEK in weather prediction (Figure 5). This in turn would help them in managing their water and vegetation resources. A key informants interview involving participants from Water Resource Association (WRA) and Water Resource Users Association (WRUA) described how they used animal behavior to interpret seasons. Certain movements of salamanders, frogs, geckos from trees and holes signaled beginning of rains. It was also noted that flowering of some indigenous trees such as Acacia tortilis and Acacia nilotica also signaled rains. As for droughts the early warning systems would include both human and animal behavior. Table 3 lists some of the drought early warning systems that the communities use.

\subsubsection{Vast Knowledge of Woody Plant Species}

Being constantly dependent on the available environmental resources and in search of forage supply for livestock, the Turkana people have acquired a wide

Table 3. Drought early warning systems utilized by the Turkana community.

\begin{tabular}{cc}
\hline Early Warning System & Signals \\
$\begin{array}{c}\text { Communities involvement in many social } \\
\text { gatherings and ceremonies e.g. marriages } \\
\text { Elders observing intestines of a goat }\end{array}$ & Drought \\
Livestock disease outbreak; increase of animal pests \\
Abnormal increase of twin births (goats/shoats) & Dry or bad season \\
Young goat continuously placing the foreleg on the head & Drought
\end{tabular}

Source: Authors' Field survey (2017).

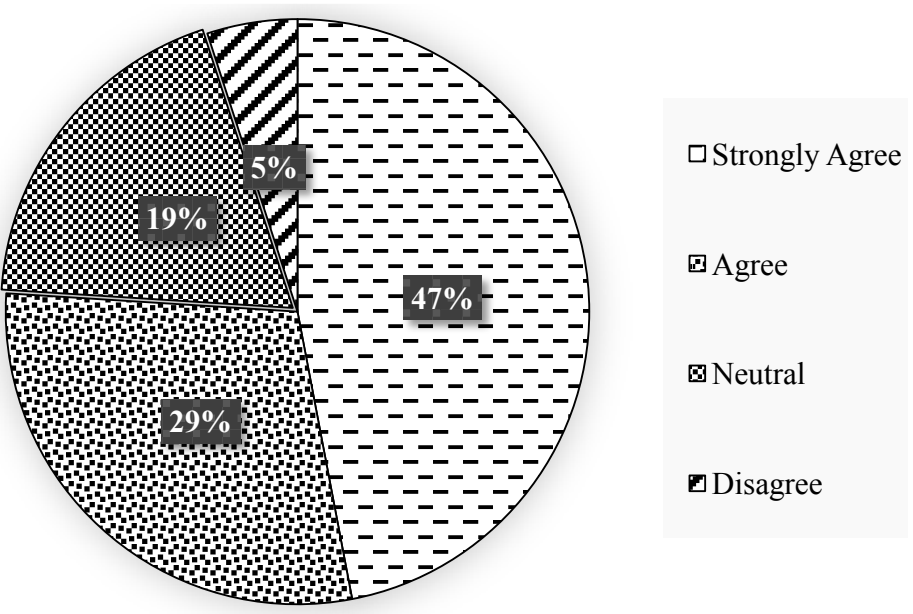

Figure 5. Respondents perceptions on TEK and weather prediction. Source: Authors' Field survey (2017). 
knowledge base on plant use. The different plants (shrubs and trees) may be utilized as human food, livestock fodder, and also have construction, manufacturing and medicinal benefits. The community is familiar with tree species that can survive the harsh environments which aside from providing fruits during dry seasons also provide fodder for animals with some being used to identify water sources. Some of the plant species and associated benefits to the Turkana Community are shown on Table 4 and Figure 6.

\subsection{Influence of TEK on Vegetation Conservation}

In assessing TEKs influence on vegetation conservation, the study revealed a positive influence whereby $69 \%$ of the respondents indicated that they practice environmental conservation because of inherited Traditional ecological knowledge. On further inquiry, the respondents described the contribution of woody

Table 4. Uses of various trees and shrub species.

\begin{tabular}{|c|c|c|}
\hline Plant Species (Tree/Shrub) & $\begin{array}{l}\text { Local Name (English/ } \\
\text { Swahili/Turkana) }\end{array}$ & Description and Uses \\
\hline Balanites aegyptiaca & Desert Date, Ebei & $\begin{array}{l}\text { Drought tolerant and evergreen tree with fruits and seeds used as food by humans } \\
\text { during dry seasons. Provides fodder for livestock }\end{array}$ \\
\hline Balanites Rotundifolia & Ebei (Turk) & $\begin{array}{l}\text { The fruits are edible, and the roots are crushed, boiled and used to treat } \\
\text { gastro-intestinal illnesses. Leaves are used as fodder for livestock. Tree produces } \\
\text { gum resin that is sold or used in manufacturing industries. }\end{array}$ \\
\hline Cordia sinensis & $\begin{array}{l}\text { Grey Leaved cordial (Eng) } \\
\text { Edome (Turk) }\end{array}$ & $\begin{array}{l}\text { Gum and fruits from the tree are edible. The plant has medicinal value as it treats } \\
\text { malaria and intestinal disorders. Grown as an ornament due to its beautiful and } \\
\text { scented flowers. }\end{array}$ \\
\hline Acacia tortilis & $\begin{array}{l}\text { Umbrella thorn (Eng) Ewoi } \\
\text { (Turk) }\end{array}$ & $\begin{array}{l}\text { Small branches are cut to feed livestock. Local residents collect pods and fruits for } \\
\text { food and fodder. Pods can be grind into nutritious flour (Apinent) and used to } \\
\text { make porridge or mixed with maize meal. The bark is used as a painkiller and in } \\
\text { treating abdominal and joint pains. } \\
\text { Flowering of the tree signals rain. }\end{array}$ \\
\hline Acacia xanthophloea & Mukongwe, Mgunga (Swahili) & $\begin{array}{l}\text { High water table indicator, Bark used for stomach upsets and in treatment of joint } \\
\text { pains. Leaves used as fodder. Provides a good habitat for birds (nest) and bees as } \\
\text { well. }\end{array}$ \\
\hline Salvadora persica & $\begin{array}{l}\text { Mustard Tree (Eng) Esokon } \\
\text { (Turk) }\end{array}$ & $\begin{array}{l}\text { Leaves and shoots are edible, can be eaten as vegetables. The roots and bark can be } \\
\text { boiled and taken as a pain killer. Widely known for its teeth cleaning properties }\end{array}$ \\
\hline Prosopis chilensis/ juliflora & $\begin{array}{l}\text { Mesquite, Mathenge (Swa), } \\
\text { Etirai (Turk) }\end{array}$ & $\begin{array}{l}\text { Drought tolerant tree with invasive characteristics. Used for shade and as an erosion } \\
\text { control tree. The seeds are used as fodder for cattle or goats. }\end{array}$ \\
\hline Acacia elatior & $\begin{array}{c}\text { River acacia (Eng) Esanya nai } \\
\text { (Turk) }\end{array}$ & $\begin{array}{l}\text { A high-water table plant indicator. Located along river banks. Planted mainly to } \\
\text { reduce soil erosion in the river banks }\end{array}$ \\
\hline Grewia Tenax & $\begin{array}{l}\text { White cross berry } \\
\text { (Eng) Engomo (Turk) }\end{array}$ & $\begin{array}{l}\text { Are a good source of pollen and nectar for bees. Leaves provide fodder for livestock } \\
\text { in dry seasons. Wood used in making bows. Different parts of the plant can treat } \\
\text { colds. The shrub is good for hedging and fencing. }\end{array}$ \\
\hline Hyphaenea compressa & $\begin{array}{c}\text { East Africa Duom palm (Eng) } \\
\text { Engol (Turk) }\end{array}$ & $\begin{array}{l}\text { The fruits are a good source of food during drought. Pulp of the fruit can be made } \\
\text { into juice. The seeds are dried and used as fuel e.g (in the smoking of fish). The stalk } \\
\text { of leaves are made into log strips and used in weaving of baskets and mats. }\end{array}$ \\
\hline
\end{tabular}

Source: Authors' Field Survey (2017). 


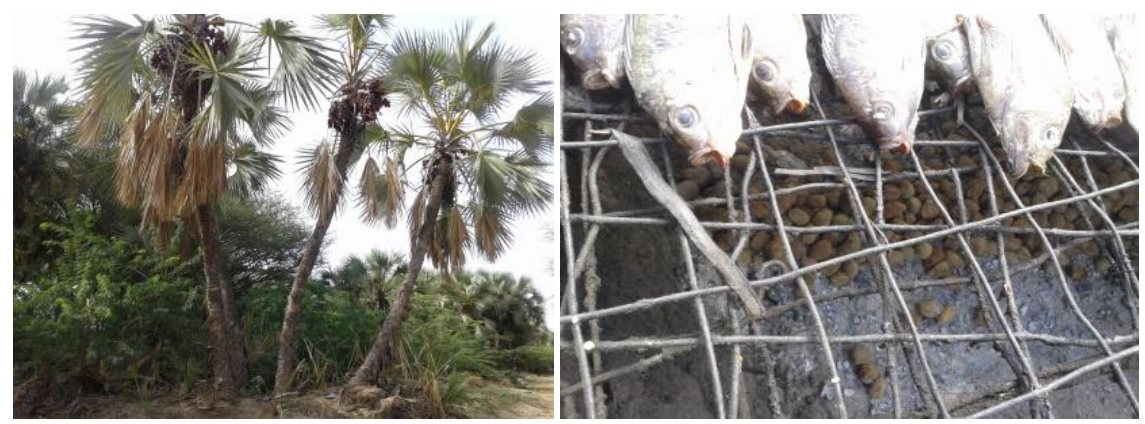

Figure 6. Use of dry palm seeds (Hyphaena compressa; Duom in Turkana language) for smoking fish. Source: Authors' Field Survey (2018).

vegetation to their livelihoods. Vegetation which include trees, shrubs and grasses is vital to the community's survival in the dryland ecosystem.

Trees are vital to the Turkana pastoral communities as they not only provide browse and fodder for livestock but also act as safety nets for dry seasons. Conservation and sustainable management of such resources has been an essential practice for the resident and is evident in their different niche exploitation mechanisms of browsers and grazers and their transhumant system of wet and dry season grazing. The creation and restoration of grazing areas was an initiative undertaken by the community and spearheaded by the elders and chiefs in the 1980's. Woodland regeneration was made possible through the Amaire and Ekwar tradition systems that ultimately resulted in the germination and growth of Acacia trees [41].

According to the FGD participants, the Amairel Epaka system (communally owned reserved set aside for dry season) accelerated woodland regeneration in the 1980's and 1990's. The Turkana residents understood the importance of having the system in place and would therefore abide by the rules.

\subsection{TEK and Water Resource Management}

\subsubsection{Siting and Conserving of Water Resource}

Access to potable water in Central Turkana is still a challenge. During droughts, residents walk for long distances, an average of $5-10 \mathrm{~km}$ in search of water for domestic and livestock use [19]. Based on FGD and KIIs their water sources are limited to ground sources which include boreholes and wells; river-bed water and surface sources that emerge from rainwater harvesting techniques. Sand dams, laggars, water pans and rock catchments are examples of rain water harvesting strategies that the Turkana pastoral community has utilized hence enabling their survival during severe periods. Laggars are holes dug out from dry riverbeds with water being extracted using containers or jericans. Water pans, on the other hand, are depressions on the ground either natural or excavated to collect run off water [42] (Figure 7). In the study area, the pans are mainly used by the herders as reservoirs for surface runoff during rainy seasons. Aside from watering livestock, residents also utilize it for domestic and agricultural purposes. 


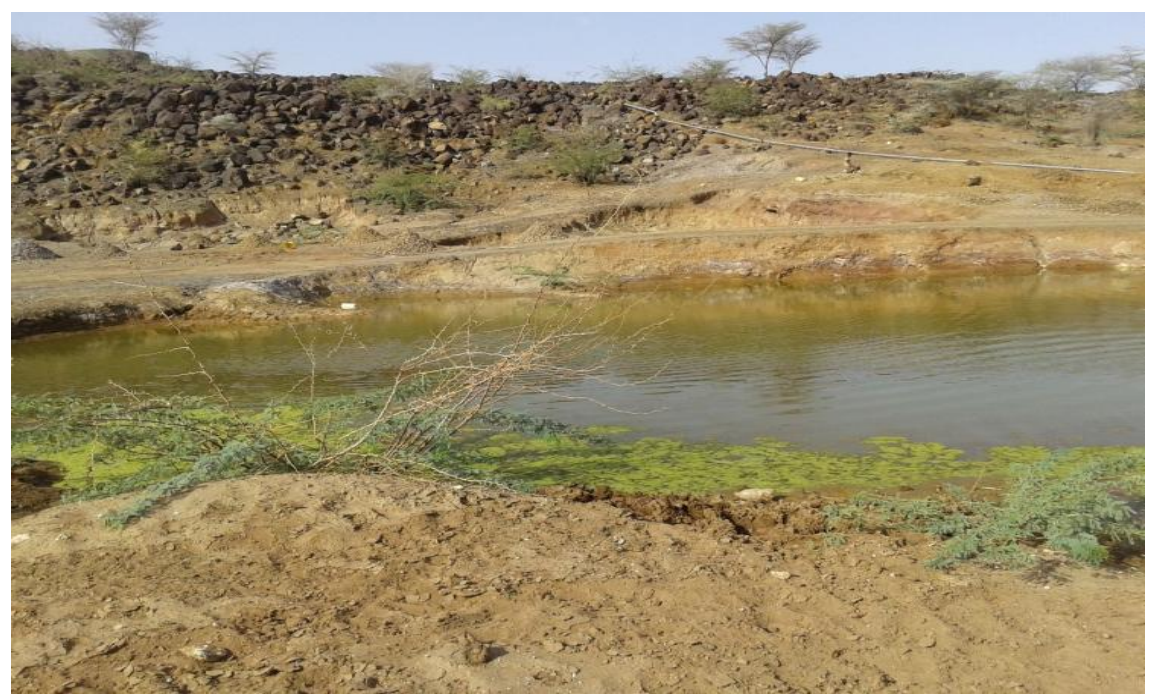

Figure 7. An excavated water pan used to trap run off water in Central Turkana. Source: Authors' Field Survey (2017).

In identifying ground water sources, the Turkana pastoralists utilize plant species as indicators of high-water table. This form of indigenous knowledge aids in successful siting of boreholes and wells. The majority of the respondents explained in detail how they have used trees like Acacia xanthophloea, Acacia elatior and Hyphaenea compressa as good indicators of high water table. On the contrary, Acacia tortilis (Ewoi) was described as a drought resistant plant mainly found in water stressed areas. Acacia tortilis is however acknowledged for its fodder and food provision during droughts.

\subsubsection{Relationship between TEK and Water Security}

The study sought to establish the relationship between key study variables. From the findings TEK has a significant impact on water security, in that; positive relationships exist between TEK and water conservation $(\mathrm{r}=0.631, \mathrm{p}<0.01$; Table 5 ). It further enhances water security through influencing the location and identification of water sources. For instance, the use of plant indicators in identifying areas with high water table and their ability to successfully site water pans and boreholes.

In spite of the positive influence TEK has on water resource management, the Turkana community still face issues of physical and economic water scarcity [33]. Frequent droughts with unreliable rainfall have been identified as the main cause of water shortage in the area [19]. Since colonial times the Kenyan ASALs suffered neglect and the areas were characterized by low investments and inadequate resource allocation. This kind of marginalization partly explains the low investments in water resource developments. In addition, the lack of political will to develop these areas and with little or no representation, the drylands were excluded from development activities and priority was given to high potential areas [21]. Further, most of these development projects hardly incorporated TEK in their food and water insecurity alleviation strategies. 
Table 5. Correlations of TEK and water security.

\begin{tabular}{|c|c|c|c|c|}
\hline & & $\begin{array}{l}\text { TEK enhances } \\
\text { Water Security }\end{array}$ & $\begin{array}{c}\text { TEK Use in } \\
\text { Water Conservation }\end{array}$ & $\begin{array}{c}\text { TEK in Siting/Identification } \\
\text { of Water Sources }\end{array}$ \\
\hline \multirow{3}{*}{$\begin{array}{l}\text { TEK enhances } \\
\text { Water Security }\end{array}$} & Pearson Correlation & 1.000 & $0.631^{\star *}$ & $0.533^{* *}$ \\
\hline & Sig. (2-tailed) & & 0.000 & 0.000 \\
\hline & $\mathrm{N}$ & 100.000 & 100.000 & 100.000 \\
\hline \multirow{3}{*}{$\begin{array}{l}\text { TEK Use in Water } \\
\text { Conservation }\end{array}$} & Pearson Correlation & $0.631^{\star *}$ & 1.000 & $0.544^{\star *}$ \\
\hline & Sig. (2-tailed) & 0.000 & & 0.000 \\
\hline & $\mathrm{N}$ & 100.000 & 100.000 & 100.000 \\
\hline \multirow{3}{*}{$\begin{array}{l}\text { TEK in Siting/Identification } \\
\text { of Water Sources }\end{array}$} & Pearson Correlation & $0.533^{* *}$ & $0.544^{\star *}$ & 1.000 \\
\hline & Sig. (2-tailed) & 0.000 & 0.000 & \\
\hline & $\mathrm{N}$ & 100.000 & 100.000 & 100.000 \\
\hline
\end{tabular}

**. Correlation is significant at the 0.01 level (2-tailed). Source: Authors' Field Survey 2017.

There have been a number of policy reforms geared towards mainstreaming ASAL challenges over the last few decades. The most important aspect of these reforms has been the acknowledgement of the importance of ASALs and committing more resources for their development. In 2008 the Ministry of State for Development of Northern Kenya and other arid lands was formed to address the challenges ASALs were facing. Consequently, a National ASAL policy was adopted in 2013 which further reinforced the provisions of the Kenya constitution and Kenya vision 2030. With an aim of enhancing sustainable development in ASALs, the policy also strengthens drylands incorporation in the national economic development planning and further institutionalizes appropriate policies that would tackle their concerns [21].

Despite the good policies in place and more investments being channeled to Turkana region, the County still faces development issues with a greater part of the population lacking access to basic needs including water and food. As Ogendi and Ong'oa [43] observed, most of the development projects in ASALs specifically those related to dam and borehole construction tend to fail as they lack input from local communities. In most cases pastoral communities are not involved in the decision-making process and the government or investor pays little attention to the cultural setting and the traditional knowledge and practices of the community.

\subsubsection{Relationship between TEK and Food Security}

There was a strong positive correlation between TEK, Food security and Pastoralism (Table 6). TEK use in pastoralism contributes to food security in that it is utilized in weather prediction, in identifying of migratory routes, in vegetation conservation and not to mention in the locating and conserving of water resources. All the aforementioned factors directly enhance livestock production which is the main source of livelihood for the Turkana community. 
Table 6. Correlations of TEK and food security.

\begin{tabular}{lccc}
\hline & & $\begin{array}{c}\text { TEK influences food } \\
\text { security }\end{array}$ & $\begin{array}{c}\text { TEK use in } \\
\text { Pastoralism }\end{array}$ \\
\hline \multirow{2}{*}{$\begin{array}{c}\text { TEK influences food } \\
\text { security }\end{array}$} & Pearson Correlation & 1.000 & $0.755^{\star *}$ \\
& Sig. (2-tailed) & & 0.000 \\
& Pearson Correlation & $0.755^{\star *}$ & 100.000 \\
TEK use in Pastoralism & Sig. (2-tailed) & 0.000 & 1.000 \\
& $\mathrm{~N}$ & 100.000 & 100.000 \\
\hline
\end{tabular}

**. Correlation is significant at the 0.01 level (2-tailed). Source: Authors' Field Survey, 2017.

\section{Conclusions}

Based on the study results, the researchers conclude that Central Turkana community possesses extensive knowledge of their environment which is valuable and widely used in their daily livelihoods. Their choice in practicing pastoralism is indeed a viable and feasible option considering their climate conditions and inadequate resources. It is a rational land use system which responds to environmental uncertainties. As opposed to the misconceptions on pastoralism, that it is a backward archaic form of production which is damaging to the environment [44], the study reveals that pastoralists are pro-environment and utilize their knowledge and skills in rangeland resource management which directly or indirectly contributes to their food and water security.

Incidences of food and water insecurity may be attributed to:

- Continuous TEK deterioration;

- Lack of support systems to fund and upgrade traditional systems;

- Lack of local community involvement in project planning and development;

- Unpredictable and harsh climatic conditions.

\section{Recommendations}

1) The National, County governments, NGO's and supporting groups need to embrace the indigenous knowledge of communities. More funds need to be allocated towards documenting and improving TEK systems.

2) Communities need to be involved in project planning and development.

3) Further research in identification and documentation of TEK relating to other natural resources need to be conducted.

\section{Acknowledgements}

We sincerely express our gratitude to JICA who through the ABE program provided the research funds for this work. We also thank Mr. G.M. Maina for the GIS maps used in this article. Our deep regards are extended to the FGD and Key Informant participants from various institutions who availed themselves and provided valuable information for this study. Finally, but not least, we ac- 
knowledge the immense support that we received from the County Government of Turkana and the National Government of Kenya institutions located in Turkana County.

\section{Conflicts of Interest}

The authors declare that there are no conflicts of interest regarding the publication of this manuscript. In addition, the ethical issues; including plagiarism, informed consent, misconduct, data fabrication and/or falsification, double publication and/or submission, redundancy have been completely observed by the authors.

\section{References}

[1] UNEMG (2011) Global Drylands: A UN System-Wide Response. Environment Management Group of the United Nations, Geneva.

[2] Irish Aid (2007) Dryland Degradation and Development (Irish Aid Development Key Sheet).

https://www.irishaid.ie/media/irishaid/allwebsitemedia/20newsandpublications/pub licationpdfsenglish/environment-keysheet-10-drylands.pdf

[3] UNCCD Secretariat (1997) United Nations Convention to Combat Desertification in Those Countries Experiencing Serious Drought and/or Desertification, Particularly in Africa. Text with Annexes Geneva. 71 p.

[4] Stewart, B. and Robinson, C. (1997) Are Agroecosystems Sustainable in Semiarid Regions. Advances in Agronomy, 60, 191-228.

https://doi.org/10.1016/S0065-2113(08)60604-5

[5] IPCC (2007) Summary for Policymakers. Climate Change 2007: The Physical Science Basis. Working Group I Contribution to IPCC Fourth Assessment Report: Climate Change 2007, Geneva.

[6] Davies, J., Poulsen, L., Schulte-Herbrüggen, B., Mackinnon, K., Crawhall, N., Henwood, W.D., Dudley, N., Smith, J. and Gudka, M. (2012) Conserving Dryland Biodiversity. Xii $+84 \mathrm{p}$.

[7] WHO (2018) Climate Change and Human Health, Land Degradation and Desertification. http://www.who.int/globalchange/ecosystems/desert/en

[8] FAO (2013) Drought Facts. FAO Land \& Water, Geneva. http://www.fao.org/docrep/017/aq191e/aq191e.pdf

[9] Abdi, O.A., Glover, E.K. and Luukkanen, O. (2013). Causes and Impacts of Land Degradation and Desertification in Sudan. International journal of Agriculture and Forestry, 3, 40-51.

[10] European Commission (ECHO) (2018) European Civil Protection and Humanitarian Aid Operations, Horn of Africa. https://ec.europa.eu/echo/printpdf/335_en

[11] Muli, J. (2014) The Impact of Irrigated Agriculture in Drylands on the Natural Environment: A Case Study of Chala Ward in Taita Taveta County, Kenya. University of Nairobi Research Archives, Nairobi.

[12] UNESCO (2003) United Nations World Water Development Report. Water for People Water for Life. http://unesdoc.unesco.org/images/0012/001297/129726e.pdf

[13] FAO (2017) Land and Water. Solutions to Water Scarcity in Agriculture; the Experience of Israel. 
http://www.fao.org/land-water/resources/events-detail/en/c/1069947/

[14] Koohafkhan, P. and Stewart, B.A. (2008) Water and Cereals in Drylands, the Food and Agriculture Organization of the United Nations. Earthscan, London. http://www.fao.org/docrep/012/i0372e/i0372e.pdf

[15] Pla Ildefonso (1996) Soil Salinization and Land Desertification. In: Rubio, J.L. and Calvo, A., Eds., Soil Degradation and Desertification in Mediterranean Environments, Geoforma Ediciones, Logroño, 105-129.

[16] NSW (2017) Type of Salinity and Their Prevention, New South Wales Government, Office of Environment and Heritage.

http://www.environment.nsw.gov.au/topics/land-and-soil/soil-degradation/salinity/ type-of-salinity-and-their-prevention

[17] Pareek, A. and Trivedi, P.C. (2011) Cultural Values and Indigenous Knowledge of Climate Change and Disaster Prediction in Rajasthan, India. Indian Journal of Traditional Knowledge, 10, 183-189.

[18] Berkes, F. (1993) Traditional Ecological Knowledge in Perspective. In: Inglis, J.T., Ed., Traditional Ecological Knowledge: Concepts and Cases, Canadian Museum of Nature, Ottawa, 1-9.

[19] County Intergrated Development Plan (CIDP) 2013-2017. Turkana County Government.

http://www.turkana.go.ke/wp-content/uploads/2016/10/Turkana-CIDP-Final-1.pdf

[20] Ndegwa, G.M. and Kiiri, I. (2011) Investigations on Soil and Water Quality as Affected by Irrigation in Turkana District, Kenya. Journal of Agriculture, Science and Technology, 12, 17-36.

[21] Odhiambo, M. (2013) Releasing Our Full Potential: The ASAL Policy, Its Promise and Challenges, A Briefing Note for Members of County Assemblies, Community Representatives, Leaders, CSO and ASAL Stakeholders, REGLAP, Nakuru.

[22] Turkana County Government TCG (2015) Second Annual Development Plan (ADP) 2015/16.

http://www.turkana.go.ke/wp-content/uploads/2016/10/Annual-Development-Plan -2015-2016.pdf

[23] Worldwatch Institute (2009) 2010 State of the World: Transforming Cultures-From Consumerism to Sustainability. Worldwatch Institute, Washington DC.

[24] United Nations Development Assistance (UNDAP), Turkana County. United Nations Joint Programme 2015-2018.

https://info.undp.org/docs/pdc/Documents/KEN/ProDoc\%20Turkana-UN\%20Join t\%20Programme\%20final\%205th\%20\%20March\%202015-binder\%20(2).pdf

[25] Turkana County Government TCG (2015) Natural Resource Mapping and Context Analysis. Final Report.

[26] Amuyunzu, C. and Oba, G. (1991) Vegetation Resources of Central Turkana District Kenya. Turkana Resource Evaluation and Monitoring Unit (TREMU) UNESCO, Nairobi.

[27] Avery, S.T. (2010) Assessment of Hydrological Impacts of Ethiopia's Omo Basin on Kenya's Lake Turkana Water Levels. Final Report Commissioned by the African Development Bank as Part of Mediation with NGO "Friends of Lake Turkana".

[28] JICA (2015) Water Potential Study in Turkana County Annex E. http://open_jicareport.jica.go.jp/pdf/12246922_05.pdf

[29] Infonent Biodivision 2017: AEZs, the Kenya System. 
http://www.infonet-biovision.org/EnvironmentalHealth/AEZs-Kenya-System

[30] Olsen, C. and St George, D.M. (2004) Cross-Sectional Study Design and Data Analysis. College Entrance Examination Board, New York.

[31] Hildebrand, E.A. and Grillo, K.M. (2012) Early Herders and Monumental Sites in Eastern Africa: Dating and Interpretation. Antiquity, 86, 338-352. https://doi.org/10.1017/S0003598X00062803

[32] Marshall, F.B., Barthelme, J.W. and Stewart, K. (1984) Early Domestic Stock at Dongodien. Azania, 19, 120-127. https://doi.org/10.1080/00672708409511332

[33] Oduor, A.R., Mutune, J., Malesu, M., et al. (2012) Food Security Master Plan for Turkana County. Diocese of Lodwar, Lodwar.

[34] Rege, J.E.O. (1999) The State of African Cattle Resources I. Classification Framework and Identification of Threatened and Extinct Breeds. FAO/UNEP Animal Genetic Resources Information Bulletin, 25, 1-25. https://doi.org/10.1017/S1014233900003448

[35] Mwai, O., Hanotte, O., Kwon, Y.-J. and Cho, S. (2015) African Indigenous Cattle: Unique Genetic Resources in a Rapidly Changing World. Asian-Australasian Journal of Animal Sciences, 28, 911-921. https://doi.org/10.5713/ajas.15.0002R

[36] An Overview of Livestock Sub-Sector (OLS) in Kenya (2018). https://pdfs.semanticscholar.org/d2c6/4979f2e84767c165ffaa7853c44003ca0056.pdf

[37] Watson, E., Kochore, H.H. and Dabasso, B.H. (2016) Camels and Climate Resilience: Adaptation in Northern Kenya. Human Ecology, 44, 701-713. https://doi.org/10.1007/s10745-016-9858-1

[38] Farah, Z. (2004) An Introduction to the Camel. In: Farah, Z. and Fischer, A., Eds., Milk and Meat from the Camel Handbook on Products and Processing, Vdf Hochschulverlag AG, ETH Zurich, Zurich/Singen, 15-22.

[39] McCabe, J.T. (1990) Turkana Pastoralism: A Case against the Tragedy of the Commons. Human Ecology, 18, 81-103. https://doi.org/10.1007/BF00889073

[40] Opiyo, F., Wasonga, O., Nyangito, M., Schilling, J. and Munang, R. (2015) Drought Adaptation and Coping Strategies among the Turkana Pastoralists of Northern Kenya. International Journal of Disaster Risk Science, 6, 295-309. https://doi.org/10.1007/s13753-015-0063-4

[41] Barrow, E. and Mlenge, W. (2003) Trees as Key to Pastoralists Risk Management in Semi-Arid Landscapes in Shinyanga, Tanzania and Turkana, Kenya. International Conference on Rural Livelihoods, Forests and Biodiversity, Bonn, 19-20 May 2003, $18 \mathrm{p}$.

[42] Mati, B. (2015) Water Pans and Ponds. http://www.jkuat.ac.ke/departments/warrec/wp-content/uploads/2015/09/WATERPANS-AND-PONDS.pdf

[43] Ogendi, G.M. and Ong'oa, I.M. (2009) Water Policy, Accessibility, and Water Ethics in Kenya. Journal of International Law, 7, 171-190.

[44] REGLAP Secretariat (2012) Key Statistics on the Drylands of Kenya, Uganda and Ethiopia. https://reliefweb.int/sites/reliefweb.int/files/resources/Annex+1+Key+Statistics+on +drylands+of+the+Horn+of+Africa_October_+2012.pdf 